\title{
Using PCR to Distinguish Diaporthe phaseolorum and Phomopsis longicolla from Other Soybean Fungal Pathogens and to Detect Them in Soybean Tissues
}

\author{
A. W. Zhang, Department of Crop Sciences; G. L. Hartman, USDA/ARS and Department of Crop Sciences, 70 \\ EASB, 1101 W. Peabody; L. Riccioni, Istituto Sperimentale per la Patologia Vegetale, Rome, Italy; W. D. Chen, \\ Illinois Natural History Survey; R. Z. Ma, Department of Animal Sciences; and W. L. Pedersen, Department of \\ Crop Sciences, University of Illinois at Urbana-Champaign, Urbana 61801-4723
}

\begin{abstract}
Zhang, A. W., Hartman, G. L., Riccioni, L., Chen, W. D., Ma, R. Z., and Pedersen, W. L. 1997. Using PCR to distinguish Diaporthe phaseolorum and Phomopsis longicolla from other soybean fungal pathogens and to detect them in soybean tissues. Plant Dis. 81:1143-1149.

Restriction fragment length polymorphism analyses of polymerase chain reaction (PCR) amplified DNA were used to distinguish Diaporthe phaseolorum and Phomopsis longicolla isolates from other soybean fungal pathogens. Primers made to the conserved sequences of nuclear ribosomal DNA amplified the internal transcribed spacer (ITS) regions of D. phaseolorum var. meridionalis and $P$. longicolla. The PCR products were cloned and then sequenced. Specific-primers, Phom.I and Phom.II, were designed from the polymorphic regions of $D$. phaseolorum and $P$. longicolla isolates from soybean to distinguish them from other soybean fungal pathogens. These ITS-derived primers amplified a 337-bp-specific DNA fragment from P. longicolla, $D$. phaseolorum var. meridionalis, $D$. phaseolorum var. caulivora, $D$. phaseolorum var. sojae, and Phomopsis spp. from 20 different hosts. No amplified product was observed using DNA of seven other soybean fungal pathogens or soybean DNA. The detection limit of PCR using primers Phom.I and Phom.II was $2.5 \times 10^{-7}$ dilution of fungal DNA extracted from samples of 10 pooled seeds and as low as a 1:15 (Phomopsis:soybean) ratio when using $10 \mathrm{ng}$ of DNA per $\mu \mathrm{l}$ from each $P$. longicolla and soybean. PCR did not produce products using primers Phom.I and Phom.II with DNA extracted from noninfected seeds, but specific bands were observed from samples of 10 pooled seeds and from individually infected seeds. A specific band was observed as well from DNA extracts of tissue samples from symptomless plants inoculated with $P$. longicolla and D. phaseolorum var. sojae.
\end{abstract}

Phomopsis seed decay of soybean (Glycine $\max (\mathrm{L}$.$) Merr.) is a major cause$ of poor quality soybean seeds in the United States and other soybean-growing areas of the world (30). The disease is caused primarily by Phomopsis longicolla T.W. Hobbs (teleomorph unknown), but Diaporthe phaseolorum (Cooke \& Ellis) Sacc. (anamorph Phomopsis phaseoli (Desmaz.) Sacc.), which has three varieties, $D$. phaseolorum var. sojae (Lehman) Wehm, D. phaseolorum var. caulivora Athow \& Caldwell, and $D$. phaseolorum var. meridionalis Fernandez $(14,19,24)$, also has been reported to be seedborne in soybeans

Corresponding author: G. L. Hartman

Email: ghartman@uiuc.edu

Names are necessary to report factually on available data; however, the USDA neither guarantees nor warrants the standard of the product, and the use of the name by USDA implies no approval of the product to the exclusion of others that may also be suitable.

Accepted for publication 17 June 1997.

Publication no. D-1997-0804-05R

This article is in the public domain and not copyrightable. It may be freely reprinted with customary crediting of the source. The American Phytopathological Society, 1997
$(1,30)$. Soybean seed mortality has been correlated with the incidence of Phomopsis seed decay fungi in seed lots (16), with a reduction in seed germination of up to $90 \%$ (21). Planting seed lots with infection levels of more than $40 \%$ has been reported to cause significant yield losses (33). Latent (21) and systemic infections (20) by $D$. phaseolorum and $P$. longicolla make it difficult to distinguish between healthy and infected plants and/or seeds. Infected seeds also may introduce the pathogen into new areas (15), and seed detection is important to avoid yield losses (9). P. longicolla also is the most important organism causing off-color soybean seeds, which is one of the primary quality-rating factors that negatively influences the market grade of soybeans $(18,29)$.

Because of the economic impact of Phomopsis seed decay, some seed-testing laboratories in the United States test soybean seed lots for the causal fungi. One commonly used procedure is the agar plate bioassay (29), which is rather labor-intensive and time-consuming. Serological methods, such as enzyme-linked immunosorbent assays (ELISA), also have been used for detecting $D$. phaseolorum and $P$. longicolla in plants and seeds $(6,17,32)$, but they are not used routinely in seedtesting laboratories. Molecular methods, such as polymerase chain reaction (PCR) coupled with restriction fragment length polymorphism (RFLP) analysis, are now widely used in fungal taxonomic and phylogenetic studies $(7,8,11,34)$, and PCRbased diagnostic methods recently have been used to detect fungal pathogens in plant tissues $(3,27)$.

Molecular genetic differences among Phomopsis spp. from different hosts have been studied by sequencing the amplified internal transcribed spacer (ITS) (25). Random amplified polymorphic DNA (RAPD) analysis was used to differentiate D. phaseolorum var. meridionalis isolates from Macrophomina phaseolina and Phoma sp. (5) and confirm the existence of at least three different subspecific taxa of D. phaseolorum that infect soybeans (13). There has been little work done, however, using molecular techniques to detect $D$. phaseolorum and $P$. longicolla in plant tissues. A molecular method that could detect the fungus in seeds may provide information needed, for example, by the European Community (EC), which requires a phytosanitary certification for soybean seed imports and does not allow importation of seeds with more than $15 \%$ seed infection by fungi causing Phomopsis seed decay (EC Directive 9.92).

The present study is a step toward the development of a PCR-based diagnostic method to detect $D$. phaseolorum and $P$. longicolla in soybean plant tissues and in soybean seeds. The objectives were to (i) use RFLP analyses of PCR-amplified DNA within the ITS regions of nuclear ribosomal DNA (rDNA) to distinguish soybean isolates of $D$. phaseolorum and $P$. longicolla from other soybean pathogens, and (ii) develop D. phaseolorum and $P$. longicolla specific-primers based on sequence analysis of the ITS region to detect these fungi in soybean plants and seeds.

\section{MATERIALS AND METHODS}

Origin of isolates and DNA extraction. $D$. phaseolorum and $P$. longicolla isolates were obtained from a wide geographic area from various contributors, while other fungal genera were isolated from soybean in Illinois (Table 1). D. phaseolorum and $P$. longicolla isolates were obtained from infected soybean seeds or stems and were single-spored. Identification was con- 
firmed on the basis of mycological descriptions $(19,24,30)$.

The fungi were grown on potato dextrose agar (PDA; Difco, Detroit, MI). Pieces of agar from the margins of actively growing colonies were used to inoculate potato dextrose broth (PDB), and cultures were grown at $24^{\circ} \mathrm{C}$ for 48 to $168 \mathrm{~h}$. Mytion at $12,000 \mathrm{rpm}$ for $10 \mathrm{~min}$. Total genomic DNA of mycelia and $1 \mathrm{~g}$ of healthy soybean plant tissues (stem and leaf) were extracted using a previously described protocol (3).

RFLP analyses of PCR-amplified DNA. ITS4 and ITS5 primers (34) were used to amplify DNA fragments from seven $P$. longicolla isolates, two $D$. phaseolorum var. meridionalis isolates, a 1:1 mixture of a $P$. longicolla isolate and a $D$. celia were collected following centrifuga-

phaseolorum var. meridionalis isolate, seven other soybean pathogens (Table 1), and healthy soybean tissue. PCR was performed with a Perkin-Elmer DNA Thermal Cycler (Applied Biosystems, Perkin-Elmer Cetus, Emeryville, CA) using $50 \mathrm{mM} \mathrm{KCl}$, $2.5 \mathrm{mM} \mathrm{MgCl} 2,10 \mathrm{mM}$ Tris- $\mathrm{HCl}$ at $\mathrm{pH}$ 8.3, $0.2 \mathrm{mM}$ each of dTTP, dATP, dGTP, $\mathrm{dCTP}, 50$ pmol of the primers, 2.5 units Taq DNA polymerase, and $25 \mathrm{ng}$ of genomic DNA in a final volume of $50 \mu \mathrm{l}$. Reactions were run for 1 cycle at $96^{\circ} \mathrm{C}$ for $5 \mathrm{~min}, 35$ cycles, each at $94^{\circ} \mathrm{C}$, for $45 \mathrm{~s}$, $53^{\circ} \mathrm{C}$ for $30 \mathrm{~s}$, and $72^{\circ} \mathrm{C}$ for $1.5 \mathrm{~min}$. The amplification efficacy was checked by agarose gel electrophoresis using $5 \mu$ of PCR products.

Twenty restriction enzymes, $A f l \mathrm{II}, A l u \mathrm{I}$, ClaI, DdeI, DraI,EcoRI, EcoRV, HgaI, HgiCI, HindIII, HinfI, MaeIII, NaeI,

Table 1. List of fungal species, isolates, their host affiliation, location of collection, and contributor used in this study

\begin{tabular}{|c|c|c|c|}
\hline Fungus & Host & Location & Contributor $^{\mathrm{a}}$ \\
\hline Cercospora sojina & Glycine $\max$ & Illinois & G. L. Hartman \\
\hline Rhizoctonia solani & G. $\max$ & Illinois & G. L. Hartman \\
\hline Macrophomina phaseolina I & G. $\max$ & Illinois & G. L. Hartman \\
\hline M. phaseolina II & G. $\max$ & Illinois & G. L. Hartman \\
\hline Fusarium solani & G. $\max$ & Illinois & G. L. Hartman \\
\hline Sclerotinia sclerotiorum & G. $\max$ & Illinois & G. L. Hartman \\
\hline Phialophora gregata & G. $\max$ & Illinois & G. L. Hartman \\
\hline Septoria glycines & G. $\max$ & Illinois & G. L. Hartman \\
\hline \multicolumn{4}{|c|}{ Diaporthe phaseolorum var. meridionalis } \\
\hline STC-5 & G. $\max$ & Arkansas & J. Rupe \\
\hline STC-2 & G. $\max$ & Arkansas & J. Rupe \\
\hline 624 & G. $\max$ & Florida & S. A. Rehner \\
\hline \multicolumn{4}{|c|}{ D. phaseolorum var. caulivora } \\
\hline 713 & G. $\max$ & Italy & A. Porta-Puglia \\
\hline 720 & G. $\max$ & Italy & A. Porta-Puglia \\
\hline \multicolumn{4}{|l|}{ D. phaseolorum var. sojae } \\
\hline AK25A & G. $\max$ & Arkansas & J. Rupe \\
\hline SW93-10 & G. $\max$ & Korea & E. W. Park \\
\hline \multicolumn{4}{|l|}{$\begin{array}{l}\text { PW93-10 } \\
\text { Phomopsis longicolla }\end{array}$} \\
\hline r1258 & G. $\max$ & Illinois & G. L. Hartman \\
\hline MO151 & G. $\max$ & Missouri & G. L. Hartman \\
\hline $\mathrm{AKl}$ & G. $\max$ & Arkansas & J. Rupe \\
\hline VS8 & G. $\max$ & Illinois & G. L. Hartman \\
\hline MO123 & G. $\max$ & Missouri & G. L. Hartman \\
\hline 3113 & G. $\max$ & Illinois & G. L. Hartman \\
\hline 3114 & G. $\max$ & Illinois & G. L. Hartman \\
\hline \multicolumn{4}{|l|}{ Phomopsis spp. } \\
\hline 570 & Oxydendrum & Virginia & S. A. Rehner \\
\hline 438 & Actinidia & California & S. A. Rehner \\
\hline 532 & Chamaecyparis & New Jersey & S. A. Rehner \\
\hline 537 & Kalmia & New Jersey & S. A. Rehner \\
\hline 533 & Epigaea & New Jersey & S. A. Rehner \\
\hline 597 & Solanum & Dominican Rep. & S. A. Rehner \\
\hline 441 & Lindera & Maryland & S. A. Rehner \\
\hline 514 & Picea & New Jersey & S. A. Rehner \\
\hline 512 & Juniperus & Virginia & S. A. Rehner \\
\hline 629 & Chamaedorea & Mexico & S. A. Rehner \\
\hline 510 & Carpinus & New Jersey & S. A. Rehner \\
\hline 487BR & Paulownia & Maryland & S. A. Rehner \\
\hline 487 & Paulownia & Maryland & S. A. Rehner \\
\hline 445 & Vaccinium & Massachusetts & S. A. Rehner \\
\hline 476 & Vaccinium & New Jersey & S. A. Rehner \\
\hline 495 & Vaccinium & Washington & S. A. Rehner \\
\hline 522 & Sassafras & New Jersey & S. A. Rehner \\
\hline 526 & Sassafras & West Virginia & S. A. Rehner \\
\hline 499 & Asparagus & New Jersey & S. A. Rehner \\
\hline 577 & Asparagus & Taiwan & S. A. Rehner \\
\hline
\end{tabular}

${ }^{a}$ G. L. Hartman, USDA/ARS, Urbana, IL; A. Porta-Puglia, Istituto Sperimentale per la Patologia Vegetale, Rome, Italy; J. Rupe, University of Arkansas; S. A. Rehner, USDA/ARS, Beltsville, MD (25).
NspBII, RsaI, SauII, Taq2, XbaI, XhoI, and XhoII, were used to generate RFLP patterns. From each sample, $5 \mu$ l of PCR product from the ITS region was digested for $4 \mathrm{~h}$ with 5 to 10 units of restriction enzyme at $37^{\circ} \mathrm{C}$. Aliquots $(20 \mu \mathrm{l})$ were loaded on a $2 \%$ horizontal agarose gel before electrophoretic separation.

DNA sequencing and sequence analysis. The ITS regions of $P$. longicolla isolates 3113 and 3114 , and D. phaseolorum var. meridionalis isolates STC-2 and STC5 , were amplified by primers ITS4 and ITS5. PCR products were size-separated by $1 \%$ agarose gel electrophoresis in Trisacetate-EDTA buffer. DNA was purified from agarose blocks using the Gel Purification Kit 50 (Qiagen Inc., Chatsworth, CA). The purified DNA was ligated into the pCR 2.1 vector and transformed into Shot competent Escherichia coli cells following the instructions of the "Original TA-Cloning Kit", Version E (Invitron Corp., San Diego, CA). Four colorless colonies were randomly selected from Luria-Bertani agar plates. After the insertion size was confirmed, selected colonies were cultured in a medium containing $4 \%$ circlegrow (Gibco BRL, Gaithersburg, $\mathrm{MD}$ ) in water at $37^{\circ} \mathrm{C}$ for $12 \mathrm{~h}$ before extracting plasmid DNA. The purified DNA was sequenced on an Applied Biosystems 373 A DNA Sequencer using DiDeoxy Dye Terminator (Applied Biosystems Division, Perkin-Elmer Cetus, Emeryville, CA).

Design of $D$. phaseolorum- and $P$. longicolla-specific primers. The DNA sequences were edited by SeqEd version 1.0.3 (Applied Biosystems Division) and analyzed by the Sequencing Analysis Package (GCG, University of Wisconsin, Madison). Based on the full-length sequences and compared with other sequence information from Phomopsis spp. (25), D. phaseolorum- and $P$. longicolla-specific primers, Phom.I and Phom.II, were designed for each selected clone with the aid of the computer program Primer Designer (version 2.0, Scientific and Educational Software, Stateline, PA). Specific primers were synthesized by the Biotechnology Center, University of Illinois at UrbanaChampaign.

Specificity of primers Phom.I and Phom.II. DNA extracted from seven other soybean fungal pathogens, three $P$. longicolla isolates, two $D$. phaseolorum var. meridionalis isolates, two $D$. phaseolorum var. caulivora isolates, two D. phaseolorum var. sojae isolates, 20 isolates of Phomopsis spp. from different hosts, and from healthy soybean tissue, were tested for their amplification with primers Phom.I and Phom.II.

P. longicolla DNA was used at a concentration of $10 \mathrm{ng} / \mu \mathrm{l}$ or diluted with soybean DNA 15 times from 1:1 to $1: 15$, and $1: 30$. DNA was extracted from a sample of 10 pooled seeds from a seed lot known to 
have $25 \%$ of the seed infected with $D$. phaseolorum and/or P. longicolla based on plating 200 seeds on PDA. Extracted DNA was suspended in $250 \mu \mathrm{l}$ of dd (double distilled) $\mathrm{H}_{2} \mathrm{O}$ and then 10-fold diluted with $\mathrm{ddH}_{2} \mathrm{O}$ to $5 \times 10^{-6}$. DNA from all dilutions was amplified with primers Phom.I and Phom.II under the PCR conditions of 1 cycle at $96^{\circ} \mathrm{C}$ for $5 \mathrm{~min}, 45 \mathrm{cy}$ cles, each at $95^{\circ} \mathrm{C}$, for $30 \mathrm{~s}, 60^{\circ} \mathrm{C}$ for $30 \mathrm{~s}$, and $72^{\circ} \mathrm{C}$ for $1 \mathrm{~min}$. The composition of each PCR reaction was the same as the PCR reactions previously mentioned, except that $2 \mu \mathrm{l}$ of extract of DNA was used per reaction for each dilution. This experiment was repeated once.

Detection of $D$. phaseolorum and $P$. longicolla from soybean seed lots and plants. Ten seed lots of cv. Williams obtained from the University of Illinois research farm in 1994 were tested by PDA plate method (29) for D. phaseolorum and $P$. longicolla infection. Seeds were treated with $95 \%$ ethanol for $30 \mathrm{~s}, 0.5 \% \mathrm{NaOCl}$ for $1 \mathrm{~min}, 2.5 \%$ paraquat (Gramoxone, Zeneca Ag Products, Wilmington, DE) for $3 \mathrm{~min}$, rinsed three times with $\mathrm{ddH}_{2} \mathrm{O}$, and then incubated in PDB for 12 to $18 \mathrm{~h}$. A microextraction technique (12) was used to extract DNA from 10 to 30 single seeds per 10 seed lots. Two $\mu \mathrm{l}$ of the extracted DNA was amplified with primers Phom.I and Phom.II. For the samples of 10 pooled seeds, the DNA was extracted using a previously described protocol (3)

In the greenhouse, 2-week-old soybean seedlings (cv. Williams) were sprayed with a mycelial suspension $\left(10^{7}\right.$ to $10^{8}$ hyphal fragments per $\mathrm{ml}$ obtained from 3-day-old cultures grown in PDB and blended for 2 min) of either $P$. longicolla isolates 3113 and $3114, D$. phaseolorum var. meridionalis isolates STC-2 and STC-5, or D. phaseolorum var. sojae isolate AK25A. Nine plants (three per replicate) were sprayed with each isolate or water. Fifteen days after inoculation, three symptomless plants were randomly sampled per isolate and the water control. Stems and petioles from each plant were cut separately into 1 $\mathrm{cm}$ lengths and leaf tissue into $1 \times 0.5 \mathrm{~cm}$ sections. These were surface-disinfected in $0.5 \% \mathrm{NaOCl}$ for $1 \mathrm{~min}$ and rinsed three times in $\mathrm{ddH}_{2} \mathrm{O}$. Five randomly selected pieces from each plant were placed on a PDA plate. DNA was extracted from randomly selected $0.2 \mathrm{~g}$ of cut fresh tissue samples using a microextraction technique (12). The DNA extracts were used in PCR assays with primers Phom.I and Phom.II ( $2 \mu \mathrm{l}$ of DNA for each reaction). DNA extracts from healthy soybean tissue were used as a control. The remaining plants that were not used for fresh tissue samples were sprayed with a $2.5 \%$ paraquat solution. Presence or absence of fungal fruiting structures on stems was recorded 10 days later. Stem sections without fungal fruiting bodies were transferred to PDA.

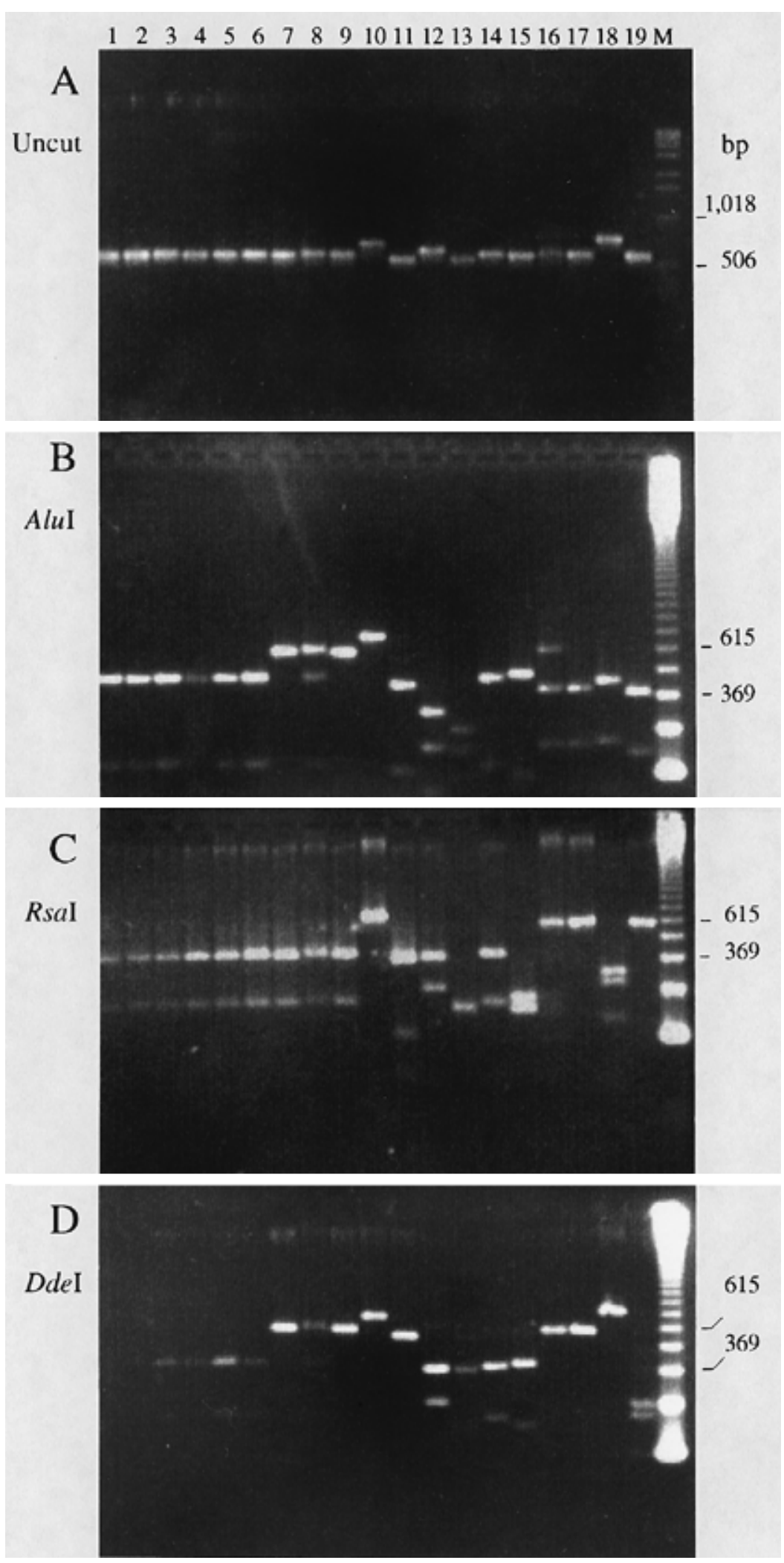

Fig. 1. Gel electrophoresis of amplified products by polymerase chain reaction (PCR) of the internal transcribed spacer (ITS) region with (A) primers ITS4 and ITS5 of different soybean fungal pathogens and soybean tissue, and banding patterns after digestion with restriction enzymes (B) AluI, (C) DdeI, and (D) RsaI. Lanes 1 to 6: isolates of Phomopsis longicolla (MO151, AKl, VS8, MO123, 3113, and 3114); lanes 7 and 9: Diaporthe phaseolorum var. meridionalis (624 and STC-2, respectively); lane 8: mixed DNA of $D$. phaseolorum var. meridionalis (STC-5) and P. longicolla (3113); lanes 10 to 19: DNA of soybean tissue, Septoria glycines, Phialophora gregata, Sclerotinia sclerotiorum, P. longicolla (r1258), Fusarium solani, Macrophomina phaseolina I, M. phaseolina II, Rhizoctonia solani, and Cercospora sojina, respectively; and lane M: molecular weight markers (Gibco-BRL) 1-kb DNA ladder in A and 123-bp DNA ladder in $\mathbf{B}$ to $\mathbf{D}$. 
In order to reduce nonspecific amplification and the effect of inhibitors in plant tissues, the hot start technique (4) was used in the PCR analysis. Two master stocks: M1 with DNA, primers, PCR buffer, and water; and M2 with dNTP, Taq polymerase, and water were added sequentially.

\section{RESULTS}

RFLP analyses of PCR-amplified DNA. PCR with primers ITS4 and ITS5 amplified fragments from 550 to $850 \mathrm{bp}$ for the nine soybean fungal pathogens. $D$. phaseolorum and $P$. longicolla isolates had a unique fragment of $605 \mathrm{bp}$ (Fig. 1A). The Phomopsis isolates were distinguished from the Diaporthe isolates after digestion only with AluI and RsaI (Fig. 1B and D). Isolates within $P$. longicolla and those within $D$. phaseolorum var. meridionalis each had distinct banding patterns. AluI, $R s a \mathrm{I}$, and DdeI produced a complete distinguishable RFLP banding pattern that distinguished $D$. phaseolorum and $P$. longicolla from other fungi (Fig. 1B to D).

DNA sequencing and design of $D$. phaseolorum- and $P$. longicolla-specific

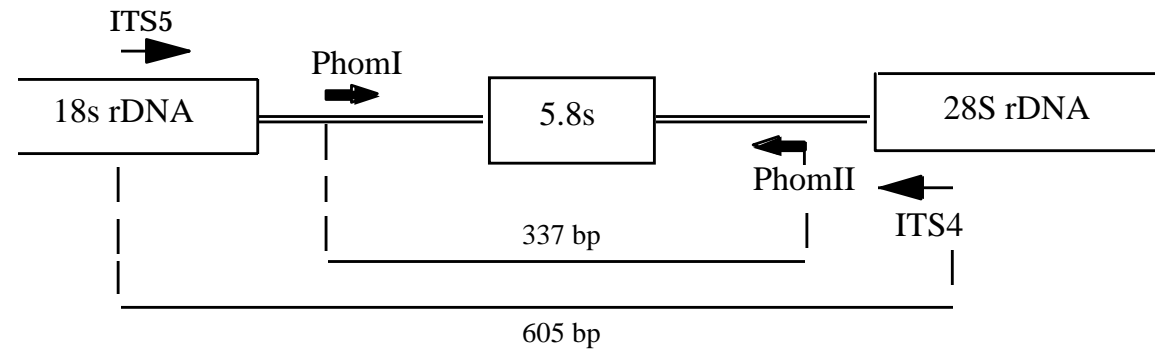

Fig. 2. Schematic locations of the Diaporthe phaseolorum- and Phomopsis longicolla-specific polymerase chain reaction primers, Phom.I and Phom.II, which amplified a 337-bp fragment (inclusive of the primer) and the "universal" internal transcribed spacer (ITS) primers ITS4 and ITS5, which amplified a 605-bp fragment of $D$. phaseolorum and $P$. longicolla rDNA.

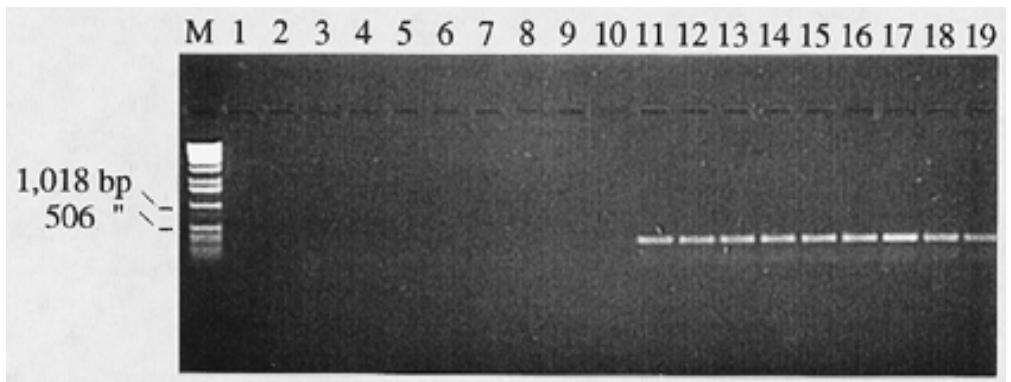

Fig. 3. Gel electrophoresis of products amplified by the polymerase chain reaction (PCR) using Diaporthe phaseolorum - and Phomopsis longicolla-specific primers Phom.I and Phom.II, and DNA from different soybean fungal pathogens. Lane M: 1-kb DNA ladder; lanes 1 to 10: Cercospora sojina, Rhizoctonia solani, Macrophomina phaseolina I, M. phaseolina II, Fusarium solani, Septoria glycines, Sclerotinia sclerotiorum, Phialophora gregata, S. glycines, and DNA of soybean tissue; lanes 11 to 13: P. longicolla ( MO151, AK1, MO123); lanes 14 and 15: Diaporthe phaseolorum var. sojae (AK25A, SW93-10); lanes 16 and 17: D. phaseolorum var. caulivora $(713,720)$; and lanes 18 and 19: D. phaseolorum var. meridionalis $(624$, STC-2).

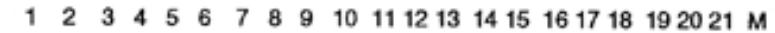

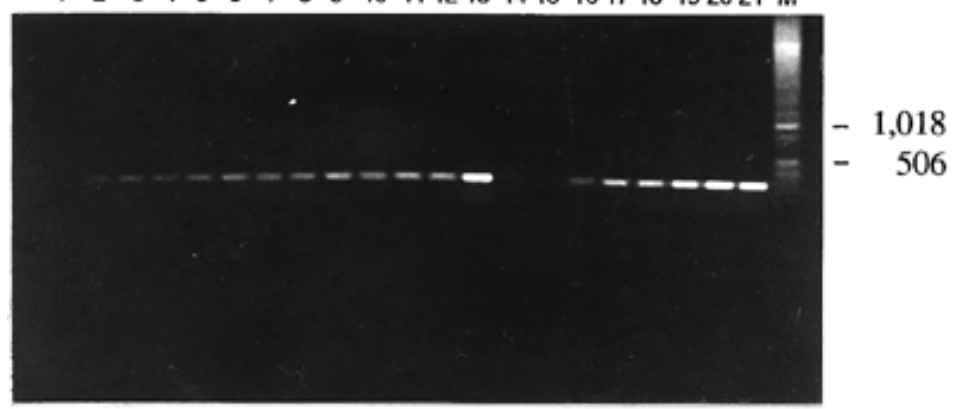

Fig. 4. Polymerase chain reaction amplification with specific primers Phom.I and Phom.II using different ratios of Phomopsis DNA with soybean DNA. Lanes 1 to 13: ratios of Phomopsis DNA with soybean DNA from 1:30 and in decreasing increments of 1:15 to 1:0; lane 14: soybean DNA; lanes 15 to $21: 5 \times$ $10^{-6}$ to $5 \times$ in $10 \times$ increments of DNA extracted from 10 pooled seeds of a seed lot with $25 \%$ of Diaporthe phaseolorum and/or Phomopsis longicolla infection; and lane M: 1-kb DNA ladder. primers. After multiple sequence alignment analysis of the ITS1 and ITS2 regions, the $D$. phaseolorum- and $P$. longicolla-specific primers were designed as: Phom.I (5'-GAGCTCGCCACTAGATTTCAGGG-3') and Phom.II (5'-GGCGGCCAACCAAACTCTTGT-3'). The primers had a GC content of 56 to $57 \%$ and were located in ITS1 and ITS2 regions, respectively, of rDNA. Their complete amplified fragment was 337 bp (Fig. 2).

Specificity of primers Phom.I and Phom.II. A 337-bp DNA fragment was amplified from all $P$. longicolla and $D$. phaseolorum isolates, but not from other soybean pathogens or soybean DNA using PCR with primers Phom.I and Phom.II (Fig. 3). Twenty Phomopsis isolates from different hosts also were amplified by the these primers.

The detection limit of PCR using primers Phom.I and Phom.II was $2.5 \times 10^{-7}$ dilution of fungal DNA extracted from samples of 10 pooled seeds and as low as a 1:15 (Phomopsis:soybean) ratio when using $10 \mathrm{ng}$ of DNA per $\mu \mathrm{l}$ from each $P$. longicolla and soybean (Fig. 4).

Detection of $D$. phaseolorum and $P$. longicolla from soybean seed lots and plants. Both DNA extraction methods produced DNA from infected soybean plants and seeds that was suitable for PCR. PCR did not produce products using primers Phom.I and Phom.II with DNA extracted from 10 pooled seeds with $0 \%$ infection (Table 2). Seed lots with 5 to $40 \%$ infection had specific bands (Fig. 5). A specific band from individually sampled infected seeds was detected with Phom.I and Phom.II. In seed lots 7 and 8, the infection percentages from single-seed PCR detections were higher than from the PDA plating (Table 2).

Soybean plants infected with isolates of $P$. longicolla and D. phaseolorum var. sojae isolate AK25A produced pycnidia on some plants 15 days after inoculation. After applying paraquat, pycnidia were observed on the stems of all inoculated plants; no pycnidia were observed on noninoculated plants. D. phaseolorum var. meridionalis did not infect plants, and neither pycnidia nor perithecia were observed on desiccated stems. The fungus was not reisolated from stem samples incubated on PDA.

PCR amplified a specific band with $D$. phaseolorum- and $P$. longicolla-specific primers using tissue samples from symptomless plants inoculated with $P$. longicolla and $D$. phaseolorum var. sojae, but not from plant samples inoculated with $D$. phaseolorum var. meridionalis (Table 3 and Fig. 6).

\section{DISCUSSION}

RFLP analyses of PCR-amplified DNA have been used to differentiate fungal isolates within the same species $(8,11)$. In our study, analysis distinguished $P$. longicolla 
and D. phaseolorum var. meridionalis from other soybean pathogens; however, based on the restriction enzymes we used, there were no differences within the isolates of $P$. longicolla and D. phaseolorum var. meridionalis.

The rDNA of related organisms generally are highly conserved, while the ITS region is less conserved (34). The more extensive sequence divergence in the ITS region has been the basis for the development of PCR assays used to detect pathogens from infected plants $(3,27)$, including soybeans (10). Using the homologous regions on both sides of the 5.8S rDNA of $D$. phaseolorum and $P$. longicolla isolates, we developed specific primers that amplified a 337-bp fragment from the ITS1 and ITS2 regions from $147 \mathrm{bp}$ to $440 \mathrm{bp}$ on the rDNA. These primers also amplified this fragment for 20 Phomopsis spp. isolates originating from different hosts, while no amplification was observed using DNA from other soybean fungal pathogens. Compared with RFLPs, these primers produced only one specific band and allowed for the detection of $D$. phaseolorum and $P$. longicolla in plant tissues.

The D. phaseolorum - and P. longicollaspecific primers have two major applications, including the detection of $D$. phaseolorum and $P$. longicolla latent infection in plants and in soybean seeds. The $D$. phaseolorum- and $P$. longicolla-specific primers detected $D$. phaseolorum and $P$. longicolla infections in symptomless tissues and potentially could be used to monitor latent infections and colonization of plants in soybean fields. This may have some predictive value in terms of evaluating infection early in the season before signs of the fungus are present. The other application could be useful for seed testing laboratories in which molecular detection may be more reliable and faster than the traditional plating of seeds on agar.

Seedborne bacterial and viral pathogens have been detected using PCR, which has been shown to be faster and more sensitive than other detection techniques $(2,22,23$, 26,28). Detection of seedborne fungal pathogens by PCR has not been extensively reported, but PCR has the potential to be routinely used in seed testing laboratories for important seedborne pathogens like $D$. phaseolorum and $P$. longicolla. Using specific primers instead of serological assays theoretically has an advantage in reducing the number of false positive reactions that may occur due to cross-reactivity of antibodies with antigens derived from the plant or other microbes. In addition, since small amounts of DNA are required for PCR assays, the problems associated with low antigen titer with ELISA can be resolved (3). Compared with plating seeds on PDA, which sometimes can mask the isolation of certain fungi when seeds have multiple infections, PCRspecific primers have high selectivity
$(10,27)$ and should be very useful for detecting target organisms on seeds with multiple infections.

The use of PCR to detect pathogens in plant tissues will become even more effective once inhibitors of PCR contained in seeds and/or plant tissues are removed $(10,13,27)$. The immunocapture method for virus detection and preincubated cultures for bacteria coupled with PCR have been effective in overcoming inhibitors $(26,28)$. In our study, seeds were soaked for $18 \mathrm{~h}$

before DNA extraction. This probably increased the amount of living fungal DNA, reduced the background of dead cell DNA, and removed PCR inhibitors by diffusion into the liquid medium (26). When coupled with the hot-start method (5), nonspecific amplification from PCR was minimized. The detection limit of PCR using primers Phom.I and Phom.II was $2.5 \times 10^{-7}$ dilution of fungal DNA extracted from samples of 10 pooled seeds.

Table 2. Detection of Diaporthe phaseolorum and/or Phomopsis longicolla in soybean seeds (cv. Williams) by potato dextrose agar (PDA) plate method and polymerase chain reaction (PCR) with specific primers Phom.I and Phom.II for 10 individual seeds and pooled samples of 10 seeds

\begin{tabular}{cccc}
\hline Seed lot & PDA plate $(\%)^{\mathbf{a}}$ & $\begin{array}{c}\text { Single seed sample } \\
\text { by PCR }(\%)^{\mathbf{b}}\end{array}$ & $\begin{array}{c}\text { Pooled sample } \\
\text { of } \mathbf{1 0} \text { seeds by PCR }\end{array}$ \\
\hline 1 & 0 & 0 & - \\
2 & 0 & 0 & - \\
3 & 20 & 20 & + \\
4 & 0 & 0 & - \\
5 & 5 & 5 & + \\
6 & 0 & 0 & - \\
7 & 25 & 30 & + \\
8 & 10 & 20 & + \\
9 & 0 & 0 & - \\
10 & 40 & 40 & + \\
\hline
\end{tabular}

${ }^{a}$ Percentage of seed infection detected by plating 200 seeds per seed lot.

${ }^{\mathrm{b}}$ Percentage based on 10 individual seeds per seed lot except in lot $5=20$ seeds and lot $8=30$ seeds. c $(-)$ absence or $(+)$ presence of specific 337-bp amplified fragments after PCR with primers Phom.I and Phom.II (Fig. 6).

Table 3. Detection of Diaporthe phaseolorum and Phomopsis longicolla in soybean plants (cv. Williams) inoculated with $D$. phaseolorum var. meridionalis, $D$. phaseolorum var. sojae, and $P$. longicolla by polymerase chain reaction (PCR) with specific primers Phom.I and Phom.II

\begin{tabular}{|c|c|c|c|c|c|c|c|}
\hline \multirow[b]{2}{*}{ Fungus } & \multirow[b]{2}{*}{ Isolate } & \multicolumn{3}{|c|}{ Infection $^{a}$} & \multicolumn{3}{|c|}{ PCR detection } \\
\hline & & Plant 1 & Plant 2 & Plant 3 & Plant 1 & Plant 2 & Plant 3 \\
\hline $\begin{array}{l}\text { D. phaseolorum var. } \\
\text { sojae }\end{array}$ & AK 25A & + & + & + & + & + & + \\
\hline D. phaseolorum var. & STC-2 & - & - & - & - & - & - \\
\hline meridionalis & STC-5 & - & - & - & - & - & - \\
\hline P. longicolla & 3113 & + & + & + & + & + & + \\
\hline & 3114 & + & + & + & + & + & + \\
\hline Control & & - & - & - & - & - & - \\
\hline
\end{tabular}

a Plant infection was determined by plating tissues on potato dextrose agar and confirming the presence of D. phaseolorum var. meridionalis, D. phaseolorum var. sojae, and P. longicolla.

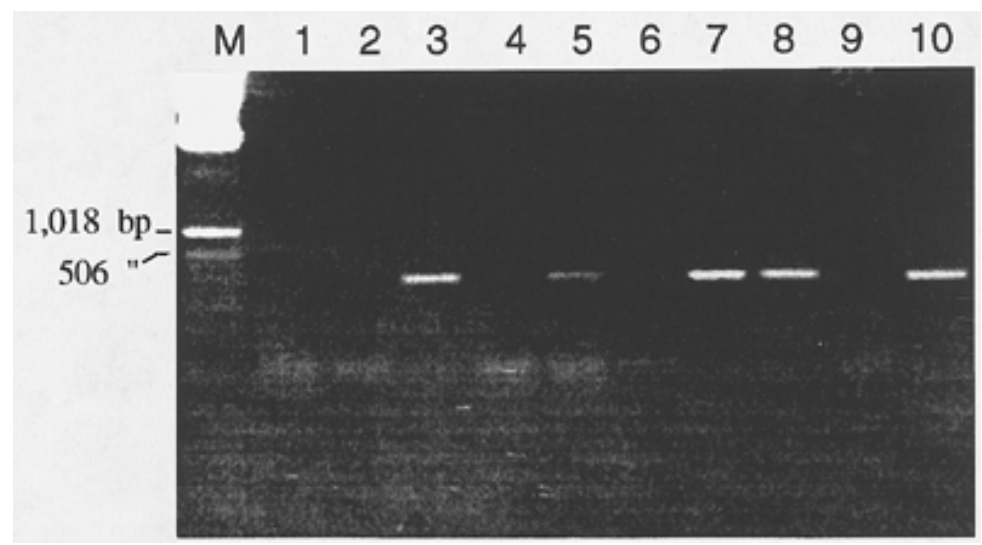

Fig. 5. Polymerase chain reaction amplification with specific primers Phom.I and Phom.II from 10 pooled seeds of seed lots (cv. Williams) with different Diaporthe phaseolorum and Phomopsis longicolla infection rates. Lane M: 1-kb ladder; lanes 1 to 10: seed lots with 0, 0, 20, 0, 5, 0, 25, 10, 0, and $40 \%$ infection rate, respectively. 


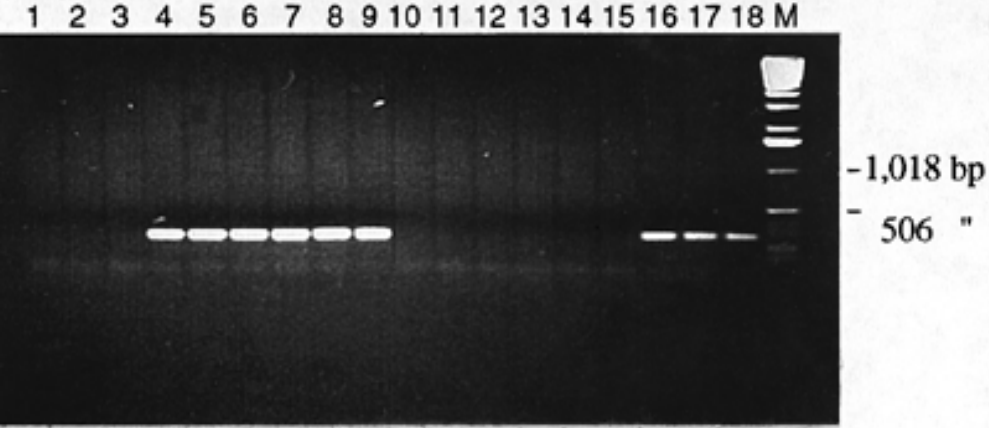

Fig. 6. Polymerase chain reaction amplification with specific primers Phom.I and Phom.II from symptomless soybean plants (cv. Williams) 15 days after inoculation with Diaporthe phaseolorum and Phomopsis longicolla isolates. The D. phaseolorum var. meridionalis inoculation was negative (Table 3). Lanes 1 to 3: water-sprayed control; lanes 4 to 6: plants inoculated with $P$. longicolla (3114); lanes 7 to 9: plants inoculated with P. longicolla (3113); lanes 10 to 12: plants inoculated with $D$. phaseolorum var. meridionalis (STC-5); lanes 13 to 15: plants inoculated with $D$. phaseolorum var. meridionalis (STC-2); lanes 16 to 18: plants inoculated with D. phaseolorum var. sojae (AK25A); and lane M: 1-kb DNA ladder.

The extraction of DNA also is a critical step for the use of PCR in seed testing. Besides the microorganisms for which $0 \%$ tolerance is required, it is necessary to purify DNA from 100 to 200 single seeds from each seed lot, which is considered a representative sample in most seed testing laboratories. The DNA micro-extraction proved to be an effective alternative, and although DNA extraction from 100 seeds was time-consuming, it may be improved by using other methods, such as a DNA fast kit, which could increase the efficiency of PCR detection by reducing PCR inhibitors while reducing the time for DNA extraction (4). In order to make PCR detection of $D$. phaseolorum- and $P$. longicolla-infected seeds more efficient, we are focusing our efforts on improving DNA extraction from soybean tissues, especially from seeds, and on the potential use of gel-free PCR (28), which could simplify the PCR detection assay.

In terms of soybean seed quality, discolored seeds are presently evaluated equally in the application of discount schedules of the market grade, even though not all discoloration may reduce seed quality. Seed infected by $D$. phaseolorum and $P$. longicolla is the number one cause of soybean seed discoloration and also is known to reduce seed quality $(18,31)$. The use of a rapid and sensitive technique to estimate the presence of $D$. phaseolorum and $P$. longicolla in seeds could present an economical advantage to producers if discount schedules for fungal-damaged soybean seeds are reevaluated.

\section{ACKNOWLEDGMENTS}

We thank Harris Lewin for the use of the sequencer, Ron Warsaw for his assistance in inoculation of plants, and J. Rupe, S. A. Rehner, E. W. Park, and A. Port-Puglia for isolates. The participation of Luca Riccioni was supported by the Ministero per le Risorse Agricole, Alimentari e Forestali of Italy (Biotechnology Program, Project No. 451, Area 10).

\section{LITERATURE CITED} bean in Ontario and the influence of production area on the incidence of Diaporthe phaseolorum var. caulivora and Phomopsis sp. Can. J. Plant Pathol. 7:74-78.

2. Audy, P., Braat, C. E., Saindon, G., Huang, H. C., and Laroche, A. 1996. A rapid and sensitive PCR-based assay for concurrent detection of bacteria causing common and halo blight in bean seed. Phytopathology 86:361-366.

3. Beck, J. J., and Ligon, J. M. 1995. Polymerase chain reaction assays for the detection of Stagonospora nodorum and Septoria tritici in wheat. Phytopathology 85:319-324.

4. Beever, J. E., Da, Y., Ron, M., and Lewin, H. A. 1994. A genetic map of nine loci on bovine chromosome 2. Mammal Genome 5:542-545.

5. Blakemore, E. J. A., Jaccoud Filho, D. S., and Reeves, J. C. 1994. PCR for the detection of Pyrenophora species, Fusarium moniliforme, Stenocarpella maydis, and Phomopsis/Diaporthe complex. Pages 205-213 in: Modern Assays for Plant Pathogenic Fungi. A. Schots, F. M. Dewey, and R. P. Oliver, ed. CAB International, Wallingford, UK.

6. Brill, L. M., McClary, R. D., and Sinclair, J. B. 1994. Analysis of two ELISA formats and antigen preparations using polyclonal antibodies against Phomopsis longicolla. Phytopathology 84:173-179.

7. Bruns, T. D., White, T. J., and Taylor, J. W. 1991. Fungal molecular systematics. Annu. Rev. Ecol. Syst. 22:525-564.

8. Buscot, F., Wipf, D., Di Battista, C., Munch, J. C., Botton, B., and Martin, F. 1996. DNA polymorphism in morels: PCR/RFLP analysis of the ribosomal DNA spacer and microsatellite-primed PCR. Mycol. Res. 100:63-71.

9. Chamberlain, D. W., and Gray, L. E. 1974. Germination, seed treatment, and microorganisms in soybean seed produced in Illinois. Plant Dis. Rep. 58:50-54.

10. Chen, W., Gray, L. E., and Grau, C. R. 1996. Molecular differentiation of fungi associated with brown stem rot and detection of Phialophora gregata in resistant and susceptible soybean cultivars. Phytopathology 86:11401148.

11. Chen, W. D., and Hoy, J. W. 1993. Molecular and morphological comparison of Pythium arrhenomanes and P. graminicola. Mycol. Res. 97:1371-1378.

12. Dellaporta, S. L., Wood, J., and Hicks, J. B. 1983. A plant DNA minipreparation: Version 2. Plant Mol. Biol. Rep. 1:19-22.
1. Anderson, T. R. 1985. Seed moulds of soy-

13. Demeke, T., and Adams, R. P. 1992. The effects of plant polysaccharides and buffer additives of PCR. Biotechniques 12:332-334.

14. Fernandez, F. A., and Hanlin, R. T. 1996. Morphological and RAPD analysis of Diaporthe phaseolorum from soybean. Mycologia 88:425-440.

15. Garzonio, D. M., and McGee, D. C. 1983. Comparison of seed and crop residues as sources of inoculum for pod and stem blight of soybeans. Plant Dis. 67:1374-1376.

16. Gleason, M. L., and Ferriss, R. S. 1985. Influence of soil water potential on performance of soybean seeds infected by Phomopsis sp. Phytopathology 75:1236-1241.

17. Gleason, M. L., Ghabrial, S. A., and Ferriss, R. S. 1987. Serological detection of Phomopsis longicolla in soybean seeds. Phytopathology 77:371-375.

18. Hepperly, P. R., and Sinclair, J. B. 1978 Quality losses in Phomopsis-infected soybean seed. Phytopathology 68:1684-1687.

19. Hobbs, T. W., Schmitthenner, A. F., and Kutter, G. A. 1985. A new Phomopsis species from soybean. Mycologia 77:535-544.

20. Kilpatrick, R. A. 1957. Fungi associated with flowers, pods, and seeds of soybeans. Phytopathology 47:131-135.

21. Kmetz, K. T., Schmitthenner, A. F., and Ellett, C. W. 1978. Soybean seed decay: Prevalence of infection and symptom expression caused by Phomopsis sp., Diaporthe phaselorum var caulivora. Phytopathology 68:836-840.

22. Leite, R. P., Jr., Jones, J. B., Somodi, G. C., Minsavage, G. V., and Stall, R. E. 1995. Detection of Xanthomonas campestris pv. vesicatoria associated with pepper and tomato seed by DNA amplification. Plant Dis. 79:917-922.

23. Maes, M., Garbeva, P., and Kamoen, O. 1996. Recognition and detection in seed of the Xanthomonas pathogens that cause cereal leaf streak using rDNA spacer sequences and polymerase chain reaction. Phytopathology 86:63-69.

24. Morgan-Jones, G. 1989. The Diaporthel Phomopsis complex: Taxonomic considerations. Pages 1699-1706 in A. J. Pascale, ed. Proc. World Soybean Res. Conf. IV. Orientacion Grafica Editora, Buenos Aires, Argentina.

25. Rehner, S. A., and Uecker, F. A. 1994. Nuclear ribosomal internal transcribed spacer phylogeny and host diversity in the coelomycete Phomopsis. Can. J. Bot. 72:1666-1674.

26. Schaad, N. W., Cheong, S. S., Tamaki, S., Hatziloukas, E., and Panopoulos, N. J. 1995. A combined biological and enzymatic amplification (Bio-PCR) technique to detect Pseudomonas syringae pv. phaseolicola in bean seed extracts. Phytopathology 85:243-248.

27. Schilling, A. G., Moller, E. M., and Geiger, H H. 1996. Polymerase chain reaction-based assays for the detection for species-specific detection of Fusarium culmorum, $F$ graminearum, and $F$. avenaceum. Phytopathology 86:515-522.

28. Schoen, C. D., Knorr, D., and Leone, G. 1996 Detection of potato leafroll virus in dormant potato tubers by immunocapture and a fluorogenic 5' nuclease RT-PCR assay. Phytopathology 86:993-999.

29. Sinclair, J. B. 1982. Seed testing: Detection of pathogens. Pages 112-115 in: Soybean Seed Quality and Stand Establishment. J. B. Sinclair and J. A. Jacobs, eds. INTSOY Ser. No. 22. University of Illinois, UrbanaChampaign.

30. Sinclair, J. B. 1995. Reevaluation of grading standards and discounts for fungus-damaged soybean seeds. J. Am. Oil Chem. Soc. 72:1415-1419.

31. Sinclair, J. B., and Backman, P. A. 1989. Compendium of Soybean Diseases. 3rd ed 
American Phytopathological Society, St. Paul, MN.

32. Velicheti, R. K., Lamison, C., Brill, L. M., and Sinclair, J. B. 1993. Immunodetection of Phomopsis species in asymptomatic soybean plants. Plant Dis. 77:70-73.
33. Wallen, V. R., and Seaman, W. L. 1963. Seed infection of soybean by Diaporthe phaseolorum and its influence on host development. Can J. Bot. 41:13-21.

34. White, T. J., Bruns, T., Lee, S., and Taylor, J. 1990. Amplification and direct sequenc- ing of fungal ribosomal RNA genes for phylogenetics. Pages 315-322 in: PCR Protocols, A Guide to Methods and Applications. M. A. Innis, D. H. Gelfand, J. J. Sninsky, and T. J. White, eds. Academic Press, San Diego, CA. 